\title{
RESEARCH OF PHARMACOLOGICAL PROPERTIES OF LAMIUM ALBUM L. HERB COMPLEXES
}

The antibacterial properties of lipophilic, phenolic complexes and dry extract and sedative activity of dry extract obtained from Lamium album (white dead-nettle) herb have been investigated. It is established that white dead-nettle dry extract shows weak, and complexes extracted with chloroform and ethyl acetate - a strong antibacterial activity against S. aureus. As for P. aeruginosa highest activity shows the phenolic complex, for C. albicans - lipophilic complex of L. album herb. Dry extract of white dead-nettle herb shows psycho-sedative properties at a dose of $100 \mathrm{mg} / \mathrm{kg}$, and the tendency to anti-hypoxic and reduce anxiety action at a dose of $10 \mathrm{mg} / \mathrm{kg}$. The dry extract exhibits greater degree of the discovered properties than the reference drug Alora ${ }^{\circledR}$. Investigated complexes are promising targets for further study of pharmacological mechanisms of antibiotic, depressive and cerebroprotective activity.

Key words: white dead-nettle; antibacterial activity; sedative activity; anti-hypoxic activity

\section{INTRODUCTION}

Dead-nettle (Lamium L.) - genus of Lamiaceae family, represented in the world flora by over 25 species; there are 7 species in the flora of Ukraine. Species of Lamium are synthesizing different groups of biological active substances (BAS) and have sufficient resource base in Ukraine. The most common species of this genus is white deadnettle - L. album L. Above-ground organs of L. album contain flavonoids, tannins, iridoids, saponins, alkaloids, essential oils and polysaccharides [10]. In folk medicine, white dead-nettle herb is used as a remedy with expectorant, anti-inflammatory, antispasmodic, diuretic, hemostatic and sedative effects. According to scientific sources extracts of this plant exhibit cytostatic, antiproliferative, antiradical activity $[5,8,9]$. A detailed study of white dead-nettle herb BAS, detection of pharmacological action of compounds complexes isolated from it, obtaining of new medicines of these complexes are actual tasks for the pharmacy.

Earlier in the L. album herb we have identified hydroxycoumarins: umbelliferone, scopoletin and aesculetin; flavonoids: isoquercitrin, quercitrin, rutin and astragalin; hydroxycinnamic acids - coffeic, chlorogenic and ferulic; by chromatography-mass spectrometry benzoic, salicylic, phenylacetic and vanillic acids were identified $[1,2]$. We have obtained lipophilic, phenolic complexes and dry extract of the white dead-nettle herb and studied composition of their BAS (flavonoids, hydroxycinnamic acids, coumarins, fatty and amino acids, volatile compounds) [7].

The aim of this study was to investigate the antibacterial properties of the obtained complexes and dry extract and sedative activity of dry extract of L. album herb.

(c) Kovaleva A. M., Goncharov A. V., Ochkur A. V., 2016
The objects of the study were lipophilic (extractant chloroform), phenolic (extractant - ethyl acetate : ethanol $96 \% 8: 2$ ) complexes and dry extract (extractant $70 \%$ ethanol) obtained from white dead-nettle herb, harvested in Kharkiv region in summer 2011 in the flowering stage.

\section{MATERIALS AND METHODS}

Determination of antibacterial activity was conducted under the guidance of the Senior Research Fellow Osolodchenko T. P. on the basis of the Kharkiv Research Institute of Microbiology and Immunology named after I. I. Mechnikov. To determine the antibacterial activity of researched substances used Mueller-Hinton agar, for the cultivation of microorganisms - nutrient agar and Saburo medium. According to WHO guidelines for the evaluation of antibacterial activity used test strains Staphylococcus aureus ATCC 25923, Pseudomonas aeruginosa ATCC 27853, Candida albicans ATCC 885/563. Microbial load amounted to 107 microbial cells per $1 \mathrm{ml}$ of medium and established using optical turbidity standards "Mc Farland". Determination of antibacterial activity carried out on two layers thick in nutrient medium, poured in a Petri dish, by agar diffusion method ("wells"). The study was conducted using $1 \%$ alcoholic solutions of the studied substances.

Sedative and antihypoxic activities of dry extract were determined at the department of pharmacology under the guidance of prof. Shtryhol S. Yu. To study the psychoactive properties of investigated extract was used a standard screening behavioral test of open field (OF), which allows to reveal nature of the impact on the CNS. Antihypoxic activity, which is the part of cerebroprotective action, studied on the model of normobaric hypoxic hypoxia with hypercapnia (NBHHH) $[3,4]$. The study was 
ANTIBACTERIAL PROPERTIES OF L. ALBUM HERB COMPLEXES

\begin{tabular}{|l|c|c|c|}
\hline \multirow{2}{*}{\multicolumn{1}{|c|}{ Complex }} & \multicolumn{2}{c|}{ The diameters of the zones of stunted growth, $\mathrm{mm}(\mathrm{M}+\mathrm{m}), \mathrm{p} \leq 0,05$} \\
\cline { 2 - 4 } & S. aureus & $20,0 \pm 0,3$ & $13,2 \pm 0,2$ \\
\hline Dry extract of L. album herb & $12,2 \pm 0,3$ & $24,3 \pm 0,2$ & $18,1 \pm 0,4$ \\
\hline Lipophilic complex of L. album herb & $30,3 \pm 0,4$ & $28,0 \pm 0,1$ & $16,4 \pm 0,1$ \\
\hline Phenolic complex of L. album herb & $30,0 \pm 0,2$ & \multicolumn{2}{c|}{ P. albicans } \\
\hline
\end{tabular}

conducted on random bred female white mice weighing 14-21 $\mathrm{g}$, which were kept in vivarium conditions. As the reference drug used syrup "Alora" containing passionflower (Passiflora incarnata L.) liquid extract. According to the literature, passionflower extract shows most pronounced psychotropic properties at the doses of $300-400 \mathrm{mg} / \mathrm{kg}$ [6], therefore in our experiment reference drug was inserted intragastric (i/g) at a dose of $375 \mathrm{mg} / \mathrm{kg}$ in the form of liquid extract. Researched dry extract was inserted i/g at doses of $10 \mathrm{mg} / \mathrm{kg}$ and $100 \mathrm{mg} / \mathrm{kg}$. As the syrup "Alora" contains a small amount of ethanol in the aqueous solution, preparation technology of researched dry extract used as excipient ethanol, as well as Tween-80 and purified water. The resulting solution was inserted to animals at the rate of $0.1 \mathrm{ml}$ to $10.0 \mathrm{~g}$ of live weight. Tests performed after the lapse of 15-25 minutes after a single insertion of substances.

\section{RESULTS AND DISCUSSION}

Results of antimicrobial activity research are shown in Table 1.

As a result of studies founded that white dead-nettle dry extract shows weak, and chloroform and ethyl acetate complexes - a strong antibacterial activity against $S$. aureus. As for P. aeruginosa highest activity shows the phenolic complex, for C. albicans - lipophilic complex of L. album herb. Dry extract proved the least active on all strains of microorganisms used for research.
The OF test results are shown in Table 2.

According to the obtained data, the study extract at a dose of $100 \mathrm{mg} / \mathrm{kg}$, and the reference drug at a dose of $375 \mathrm{mg} / \mathrm{kg}$ after a single insertion exhibit a pronounced psychosedative effect which manifests through reduction of motor and orientation-research activity by $26.6 \%$ and $35.7 \%$ respectively. Depressive effect on the CNS is more pronounced for the dead-nettle herb extract than "Alora" syrup, and equally were observed depression of horizontal (32\% compared with the control) and vertical (50\% compared with the control, $\mathrm{p}<0.05$ ) components.

A distinctive feature of the complex action of deadnettle $100 \mathrm{mg} / \mathrm{kg}$ is pronounced reduction of vegetative support of emotional reaction (2 times decrease in the number of defecation, urination and grooming acts). This property of dry extract may be the component of stressprotect action and used for correcting of neurogenic vegetative disorders.

Single-dose dead-nettle dry extract at a dose of $10 \mathrm{mg} / \mathrm{kg}$ does not exert sedation, however, it reduces quantity of vertical activity (stands) by $46 \%$ compared with the control. Lack of motivation to study an unknown location in animals and reduced the frequency of grooming characteristic for action of dead-nettle herb extract at $10 \mathrm{mg} / \mathrm{kg}$ may be due to its tranquilizing activity.

Thus, a single insertion of white dead-nettle dry extract at a dose of $100 \mathrm{mg} / \mathrm{kg}$, according to the $\mathrm{OF}$ test, demonstrated a more pronounced psychosedative effect on

Table 2

\section{RESULTS OF “OPEN FIELD” TEST AFTER THE INSERTION OF DRY EXTRACT OF WHITE DEAD-NETTLE} AND REFERENCE DRUG

\begin{tabular}{|l|c|c|c|c|}
\hline \multicolumn{1}{|c|}{ Indicators (for $3 \mathrm{~min})$} & $\begin{array}{c}\text { Control }(0.9 \% \\
\mathrm{NaCl} \mathrm{i} / \mathrm{g}, \mathrm{n}=6)\end{array}$ & $\begin{array}{c}\text { "Alora" syrup } \\
(375 \mathrm{mg} / \mathrm{kg} \mathrm{i} / \mathrm{g}, \mathrm{n}=6)\end{array}$ & $\begin{array}{c}\text { Extract }(10 \mathrm{mg} / \mathrm{kg} \\
\mathrm{i} / \mathrm{g}, \mathrm{n}=6)\end{array}$ & $\begin{array}{c}\text { Extract }(100 \mathrm{mg} / \mathrm{kg} \\
\mathrm{i} / \mathrm{g}, \mathrm{n}=6)\end{array}$ \\
\hline Locomotor activity: Number of squares & $75.67 \pm 10.94$ & $\begin{array}{c}54.33 \pm 10.29 \\
(-28.2 \%)\end{array}$ & $\begin{array}{c}76.50 \pm 9.31(+ \\
1.09 \%)\end{array}$ & $\begin{array}{c}51.50 \pm 6.70 \\
(-31.94 \%)\end{array}$ \\
\hline Orientation-research activity: Stands & $23.17 \pm 3.60$ & $\begin{array}{c}12.50 \pm 1.14^{*} \\
(-46.05 \%)\end{array}$ & $\begin{array}{c}12.50 \pm 2.78^{*} \\
(-46.05 \%)\end{array}$ & $\begin{array}{c}5.00 \pm 1.63^{*} \\
(-78.42 \%)\end{array}$ \\
\hline Holes & $39.33 \pm 2.78$ & $\begin{array}{c}31.17 \pm 7.20 \\
(-20.75 \%)\end{array}$ & $\begin{array}{c}44.67 \pm 3.60(+ \\
13.58 \%)\end{array}$ & $\begin{array}{c}29.50 \pm 3.60 \\
(-25.00 \%)\end{array}$ \\
\hline Sum & $62.5 \pm 2.29$ & $43.67 \pm 7.52^{*}$ & $47.17 \pm 6.05$ & $31.17 \pm 4.9^{*}$ \\
\hline Emotion reactions: Boluses & $1.33 \pm 0.16$ & $2.00 \pm 0.98$ & $1.33 \pm 0.65$ & $0.33 \pm 0.16^{*}$ \\
\hline Urinations & $0.5 \pm 0.16$ & $0.00 \pm 0.00$ & $0.50 \pm 0.16$ & $0.67 \pm 0.16$ \\
\hline Grooming & $2.0 \pm 0.65$ & $2.33 \pm 1.31$ & $0.83 \pm 0.49$ & $1.50 \pm 0.82$ \\
\hline Sum & $3.83 \pm 0.49$ & $5.0 \pm 1.31$ & $2.67 \pm 0.82$ & $2.50 \pm 0.98$ \\
\hline Sum of all types of activity & $140.33 \pm 13.56$ & $\begin{array}{c}103.0 \pm 18.6 \\
(-26.60 \%)\end{array}$ & $\begin{array}{c}136.33 \pm 14.54 \\
(-2.85 \%)\end{array}$ & $\begin{array}{c}90.17 \pm 11.27^{*} \\
(-35.74 \%)\end{array}$ \\
\hline
\end{tabular}

Note: * - significant changes in the control group $(\mathrm{p}<0.05)$ 


\section{THE LIFETIME OF THE MICE IN SEALED CHAMBER AFTER THE INSERTION OF DRY EXTRACT OF WHITE DEAD-NETTLE AND REFERENCE DRUG}

\begin{tabular}{|c|c|c|}
\hline Group, preparation, dose & The lifetime of the mice, s & $\begin{array}{c}\text { Change \% compared with the } \\
\text { control }\end{array}$ \\
\hline Control $(0.9 \% \mathrm{NaCl} \mathrm{i} / \mathrm{g}, \mathrm{n}=6)$ & $3184.67 \pm 393.13$ & - \\
\hline "Alora" $(375 \mathrm{mg} / \mathrm{kg} \mathrm{i} / \mathrm{g}, \mathrm{n}=6)$ & $3346.33 \pm 1076.96$ & +5.08 \\
\hline Dry extract $(10 \mathrm{mg} / \mathrm{kg} \mathrm{i} / \mathrm{g}, \mathrm{n}=6)$ & $3726.33 \pm 1279.11$ & +17.01 \\
\hline Dry extract $(100 \mathrm{mg} / \mathrm{kg} \mathrm{i} / \mathrm{g}, \mathrm{n}=6)$ & $2111.33 \pm 234.64^{*}$ & -33.70 \\
\hline
\end{tabular}

Note: ${ }^{*}$ - significant changes in the control group $(\mathrm{p}<0.05)$.

the CNS than using known hypnotic - "Alora" syrup. Dry extract at a dose of $10 \mathrm{mg} / \mathrm{kg}$ after a single insertion provides a tranquilizing effect (reducing anxiety), not showing sedation.

In conditions of NBHHH test (Table 3) mouse lived in a hermetically sealed chamber on average during $3185 \mathrm{c}$. Insertion of dead-nettle dry extract manifested itself as follows: reducing the lifetime of the mice in the high dose $(100 \mathrm{mg} / \mathrm{kg}$ ) to $33.7 \%$ ( $<<0.05$ for control) but statistically unreliable ( $p>0.05)$ increasing it to $17 \%$ in the low dose $(10 \mathrm{mg} / \mathrm{kg})$. Thus, we can conclude tendency to the presence of antihypoxic properties of dead-nettle dry extract in dose $10 \mathrm{mg} / \mathrm{kg}$.

Insertion of dead-nettle dry extract manifested itself as follows: reducing the lifetime of the mice in the high dose $(100 \mathrm{mg} / \mathrm{kg}$ ) to $33.7 \%$ ( $\mathrm{p}<0.05$ for control) but statistically unreliable ( $p>0.05$ ) increasing it to $17 \%$ in the low dose $(10 \mathrm{mg} / \mathrm{kg})$. Thus, we can conclude tendency to the presence of antihypoxic properties of dead-nettle dry extract in dose $10 \mathrm{mg} / \mathrm{kg}$.

In these conditions, the reference drug had almost no effect on the recorded index, showing a tendency to increase it of $5.1 \%$.

\section{CONCLUSIONS}

Lipophilic and phenolic complexes obtained from white dead-nettle herb show a strong antibacterial activity against $S$. aureus, $P$. aeruginosa and antifungal activity against $C$. albicans.

Dry extract of white dead-nettle herb shows psychosedative properties at a dose of $100 \mathrm{mg} / \mathrm{kg}$, and the tendency to antihypoxic action and reduce anxiety in a dose of $10 \mathrm{mg} / \mathrm{kg}$. The dry extract exhibits greater degree of the discovered properties than the reference drug Alora ${ }^{\circledR}$ effective and well-known in Ukraine plant hypnotic.

Investigated complexes are promising targets for further study of pharmacological mechanisms of antibiotic, depressive and cerebroprotective activity.

\section{REFERENCES}

1. Буреш Я. Методики и основные эксперименты по изучению мозга и поведения / Я. Буреш, О. Бурешова, Д. П. Хьюстон. - М.: Высш. шк., 1991. C. $119-122$.
2. Гончаров О. В. Дослідження фенольних сполук трави кропиви глухої білої та кропиви глухої пурпурової / О. В. Гончаров, А. М. Ковальова, О.В.Горяча // Теоретичні та практичні аспекти дослідження лікарських рослин: матер. I міжнар. наук.-практ. Internet-конф., м. Харків, 20-21 берез. 2014 р. Х.: Вид-во НФаУ, 2014. - С. 69-70.

3. Ковальова А. М. Дослідження компонентного складу ефірної олії квіток Lamium album / А. М. Ковальова, Я. С. Колісник, О. В. Гончаров, Т. В. Ільїна // Запорожский мед. журн. - 2012. - № 3 (72). C. 74-75.

4. Руководство по проведению доклинических исследований лекарственных средств / Под ред. докт. мед. наук А. Н. Миронова. - Ч. І. - М.: Гриф и К, 2012. - 944 c.

5. Bubueanu C. Antioxidant activity of butanolic extracts of Romanian native species - Lamium album and Lamium purpureum / C. Bubueanu, C. Gheorghe, L. Pirvu, G. Bubueanu // Romanian Biotechnol. Let. - 2013. Vol. 18, № 6. - P. 8855-8862.

6. Grundmann O. Anxiolytic effects of a passion flower (Passiflora incarnata L.) extract in the elevated plus maze in mice / O. Grundmann, C. Wähling, C. Staiger, V. Butterweck // Pharmazie. - 2009. - № 64 (1). P. 36-64.

7. Ochkur 0. Amino acids and monosaccharides composition of white dead-nettle (Lamium album L.) herb extract / O. Ochkur, A. Kovalyova, O. Goncharov, A. Komisarenko // The Pharma Innovation J. - 2015. № 4 (3). - P. 45-48.

8. Paduch R. Lamium album extracts express free radical scavenging and cytotoxic activities / R. Paduch, G. Matysik, M. Wójciak-Kosior // Polish J. of Environ. Stud. - 2008. - Vol. 17, № 4. - P. 569-580.

9. Soulimani R. Behavioural effects of Passiflora incarnata L. and its indole alkaloid and flavonoid derivatives and maltol in the mouse / R. Soulimani // J. Ethnopharmacol. - 1997. - № 57 (1). P. 11-20.

10. Yalçin F. N. Ethnobotany, pharmacology and phytochemistry of the genus Lamium (Lamiaceae) scientific review / Funda N. Yalçin, Duyugu Kaya // Fabad J. Pharm. Sci. - 2006. - Vol. 31. - P. 43-52. 


\section{УДК 615.214.24:615.281.9:582.929.4}

А. М. Ковальова, О. В. Гончаров, О. В. Очкур ДОСЛІДЖЕННЯ ФАРМАКОЛОГІЧНИХ ВЛАСТИВОСТЕЙ КОМПЛЕКСІВ ТРАВИ LAMIUM ALBUM L.

Досліджені антибактеріальні властивості ліпофільного, фенольного комплексів і сухого екстракту та седативна активність сухого екстракту трави L. album. Встановлено, що сухий екстракт глухої кропиви білої проявляє слабку, а хлороформний та етилацетатний комплекси - виражену антибактеріальну активність по відношенню до S. aureus. Щодо P. aeruginosa найвищу активність демонструє фенольний комплекс, щодо C. albicans - ліпофільний комплекс трави L. album. Сухий екстракт глухої кропиви білої проявляє психоседативні властивості в дозі 100 мг/кг, а також тенденцію до антигіпоксичної дії та зниження тривоги в дозі 10 мг/кг. Виявлені властивості сухий екстракт проявляє в більшій мірі, ніж препарат порівняння Алора ${ }^{\circledR}$. Досліджувані комплекси $є$ перспективними об'єктами для подальшого фармакологічного вивчення на предмет механізмів антибактеріальної, депримуючої і церебропротекторної активності.

Ключові слова: Глуха кропива біла; антибактеріальна активність; седативна активність; антигіпоксична активність

\section{УДК 615.214.24:615.281.9:582.929.4}

\section{А. М. Ковалева, А. В. Гончаров, А. В. Очкур}

ИССЛЕДОВАНИЕ ФАРМАКОЛОГИЧЕСКИХ СВОЙСТВ КОМПЛЕКСОВ ТРАВЫ LAMIUM ALBUM L.

Исследованы антибактериальные свойства липофильного, фенольного комплексов и сухого экстракта и седативная активность сухого экстракта травы L. album. Установлено, что сухой экстракт яснотки белой проявляет слабую, а хлороформный и этилацетатный комплексы - выраженную антибактериальную активность по отношению к S. aureus. Относительно P. aeruginosa высокую активность демонстрирует фенольный комплекс, относительно C. albicans - липофильный комплекс травы L. album. Сухой экстракт яснотки белой проявляет психоседативные свойства в дозе 100 мг/кг, а также тенденцию к антигипоксическому действию и снижению тревоги в дозе 10 мг/кг. Выявленные свойства сухой экстракт проявляет в большей степени, чем препарат сравнения Алора ${ }^{\circledR}$. Исследуемые комплексы являются перспективными объектами для дальнейшего фармакологического изучения на предмет механизмов антибактериальной, депримирующей и церебропротекторной активности.

Ключевые слова: Яснотка белая; антибактериальная активность; седативная активность; антигипоксическая активность

Адреса для листування:

Надійшла до редакції 31.03.2016 p.

61168, м. Харків, вул. Валентинівська, 4.

Національний фармацевтичний університет 